\title{
Physical characterization manure of the variation adding earthworms $L$. lumberus the process Vermicomposting
}

\author{
Vivin Setiani ${ }^{*}$, Vely Kukinul Siswanto ${ }^{2}$, Ayu Nindyapuspa $^{3}$, Ummi Fadilillah Kurniawati ${ }^{4}$, \\ and Mutiara Mayang Kamilah ${ }^{5}$ \\ ${ }^{1,3,5}$ Department of Waste Treatment Engineering, Marine Engineering, Shipbuilding Institute of \\ Polytechnic Surabaya, Jl. Teknik Kimia, Kampus ITS Sukolilo, Surabaya, Indonesia \\ ${ }^{2,4}$ Department of Urban and Regional Planning, Faculty of Civil Planning and Geo Engineering, \\ Sepuluh Nopember Institute of Technology (ITS) Surabaya, Jl. Despro, Building A 2nd Floor of \\ ITS Campus, Sukolilo Surabaya
}

\begin{abstract}
Composition of organic waste in Surabaya was $54.31 \%$ of the total generated waste. One of the biodegradable organic waste is banana peel and sawdust. There are a lack of processing banana peels and sawdust into useful products. The variation of vermicompost materials in this research were vegetable waste $(27 \%)$, banana peels $(27 \%)$, and sawdust (46\%). The physical characteristics of compost (temperature, moisture content, texture, color, particle size of compost, shrinkage of compost material and weight of L.lumberus worms) were analyzed. The results of this study shown that the physical characteristics of compost in reactors 1 (no adding worms), 2 (adding $100 \mathrm{gr}$ worms $/ \mathrm{kg}$ organic waste), and 3 (adding $250 \mathrm{gr}$ worms $/ \mathrm{kg}$ organic waste) (temperature, texture and color) have met the standards (Indonesian National Standard number 7763:2018 and 19-7030-2004) but the moisture content did not meet the standards. R2 has a percentage of decreasing of worms about $16.4 \%$ of worms but the worms in R3 increased up to $8.3 \%$ of worm weight. The shrinkage of compost material in R1, R2, and R3 was $64.67 \%, 76.45 \%$; and $71.01 \%$, respectively.
\end{abstract}

\section{Introduction}

Market waste that is not treated properly will result in environmental pollution. Most traditional markets in Indonesia have not been able to manage waste so that waste accumulates in final disposal sites. This causes the generation of waste to increase every year. Vegetable waste is organic waste that can be used as raw material for manure because it contains high macro and micro nutrients, and the speed of decomposition of compost is high [1].

One of the organic waste that has not been utilized optimally is banana peel. Banana peel is also one of the wastes generated from production activities in the home industry. Banana peel waste is not utilized and only disposed of in a landfill. In addition, other

$\overline{{ }^{*} \text { Corresponding author: vivinsetiani@ppns.ac.id }}$ 
organic wastes such as sawdust account for about $45 \%$ of the total waste generated in the furniture industry. Bark and sawdust are generally burned and will cause environmental pollution [2].

One alternative to the composting method of organic solid waste is the vermicomposting method. Vermicomposting is a process of decomposing organic waste with the help of earthworms which produces manure with high $\mathrm{C} / \mathrm{N}$ ratio yields and is superior to conventional composting $[3,4]$. Vermicomposting is a technology whose operations require low costs and can reduce the generation of organic waste [5]. According to [6], a good type of worm to use is a brightly color epigeic worm such as Lumbricuss rubellus (L.lumberus) in the vermicomposting method. The waste that will be used for composting is first sorted to separate non-biodegradable and biodegradable waste [7]. The manure produced from the vermicomposting process contains nutrients for organic soil that can add nutrients to the soil $[8,9]$.

Banana plants are one of the organic wastes that can be composted using earthworms because the content of $\mathrm{N}, \mathrm{P}$ and $\mathrm{K}$ in the vermicomposting process is very high [10]. Banana peel is one of the waste parts of the banana plant. Banana peel has a high organic $\mathrm{C}$ content so that it can create an ideal $\mathrm{C} / \mathrm{N}$ ratio condition for the vermicomposting process. The addition of sawdust affect to the growth of earthworm L. lumberus in the reactor $[11,12]$. In addition, sawdust has a high organic $\mathrm{C}$ which can create an ideal and stable $\mathrm{C} / \mathrm{N}$ in the vermicomposting process [13]. Therefore, in this study the composition of the compost material consisted of banana peel waste, vegetables and sawdust.

According to [14], vermicompost has a high main nutritional content consisting of $1.108 \%$ nitrogen, $0.669 \%$ phosphorus and $1.318 \%$ potassium. This research used 100 grams of earthworms for every 2 kilograms of organic waste. In this study, the variation of worm weight was $100 \mathrm{gram} / \mathrm{kg}$ organic waste and $250 \mathrm{gram} /$ organic waste. This aims to determine the physical characteristics of manure from variations in the addition of earthworm L. lumberus in decomposing organic waste.

\section{Material and methods}

The research method were as follows:

\subsection{Design of composter}

The following were the steps in making a vermicomposting reactor

\subsubsection{Measurement of the levels of C-Organic, $N$-Total and $C / N$ ratio in each banana peel and sawdust before composting was carried out.}

The results of the initial $\mathrm{C} / \mathrm{N}$ ratio measurement of each compost material to be composted. C-organic measurement of material compost have used spectrophotometer wavelength $651 \mathrm{~nm}$ with a standard solution of $5000 \mathrm{ppm}$ C. In addtion, N-total measurement of material compost have used khjedahl flask titration with $0.05 \mathrm{~N}$. standard $\mathrm{H}_{2} \mathrm{SO}_{4}$ solution. Result of measurement $\mathrm{C} / \mathrm{N}$ ratio in material compost were 8 (vegetable waste), 82 (banana peel) and 110 (sawdust).

This data is used to calculate the ideal composition of compost material (as seen as on chapter 2.1.2) in the vermicomposting process. 


\subsubsection{Calculation of the composition of the compost material based on the $\mathrm{C} / \mathrm{N}$ ratio of organic waste}

In this study, the organic waste was composted of vegetable waste, banana peels and sawdust. According to [13] the $\mathrm{C} / \mathrm{N}$ ratio of organic waste was suggested at the beginning of the vermicomposting process of 23-70. In this study, the initial $\mathrm{C} / \mathrm{N}$ ratio of vermicomposting used 82 because it was close to the $\mathrm{C} / \mathrm{N}$ ratio value of 70 .

The following was the calculation of the $\mathrm{C} / \mathrm{N}$ ratio of compost raw materials in this study $[29,30]$.

$$
\begin{gathered}
\frac{C}{N}=\frac{C(1 \mathrm{Kg} \text { vegetable waste })+C(1 \mathrm{Kg} \text { banana peel waste })+X C(1 \mathrm{Kg} \text { sawdust })}{N(1 \mathrm{Kg} \text { vegetable waste })+N(1 \mathrm{Kg} \text { banana peel waste })+X N(1 \mathrm{Kg} \text { sawdust })} \\
(1) \\
82=\frac{28,6(1 \mathrm{Kg} \text { vegetable waste })+45,46(1 \mathrm{Kg} \text { banana peel waste })+X 52,97(1 \mathrm{Kg} \text { sawdust })}{3,34(1 \mathrm{Kg} \text { vegetable waste })+0,55(1 \mathrm{Kg} \text { banana peel waste })+X 0,48(1 \mathrm{Kg} \text { sawdust })}
\end{gathered}
$$

$$
\mathrm{X}=1,68 \mathrm{~kg}
$$

This showed that $1.68 \mathrm{~kg}$ of sawdust is mixed with $1 \mathrm{~kg}$ of vegetable waste and $1 \mathrm{~kg}$ of banana peel waste so that the composition of waste that was composted is $46 \%$ sawdust, $27 \%$ vegetable waste and $27 \%$ banana peels. Table 1 presented that research variable in thi study which R1 (no adding worms), R2 (adding $100 \mathrm{gr}$ worms $/ \mathrm{kg}$ organic waste) and R3 (adding 250 gr worms $/ \mathrm{kg}$ organic waste). Composition in material compost consist of $46 \%$ sawdust, $27 \%$ vegetable waste and $27 \%$ banana peels with a dose of EM4 $(30 \mathrm{ml} / \mathrm{Kg}$ organic waste.

Table 1. Research Variables

\begin{tabular}{|l|l|l|l|}
\hline $\begin{array}{l}46 \% \text { sawdust, } 27 \% \\
\text { vegetable waste and } \\
27 \% \text { banana peels with } \\
\text { a dose of EM4 (30 } \\
\text { m1/Kg organic waste }\end{array}$ & $\begin{array}{l}\text { No worms } \\
\text { (0 g/kg organic waste) }\end{array}$ & $\begin{array}{l}\text { Worms }(\mathbf{1 0 0} \mathbf{~ g r} / \mathbf{k g} \\
\text { organic waste) }\end{array}$ & $\begin{array}{l}\text { worms (250 gr/kg } \\
\text { organic waste) }\end{array}$ \\
\cline { 2 - 4 } R1 & $\mathrm{R} 2$ & $\mathrm{R} 3$ \\
\hline$R 1:$ Reactor 1 \\
$R 2:$ Reactor 2 \\
$R 3:$ Reactor 3
\end{tabular}

\subsubsection{Calculation of the volume of compost material}

In this study measurement of the density of the compost to calculate the volume of the compost material. Measurement of the density of the compost mixture used the density measurement method and waste generation [26]. Based on the results of the measurement of the density of the compost $m$ material, the density of the compost material in reactors 1 , 2 and 3 were $474.5 \mathrm{~kg} / \mathrm{m}^{3}$ respectively.

The formula for calculating the volume of the compost material.

$$
\text { volume of compost material }=\frac{\text { mass of compost material }}{\text { density of compost material }}
$$

Thus, the volume of compost material $=24000 \mathrm{~cm}^{3}$ 


\subsubsection{The calculation of the volume of the composter}

The type of reactor in this study was a block shaped container with bed as seen as on Figure 1. This reactor was made of wood and surrounded by sacks which function to maintain air humidity and air circulation in the reactor.

The formula for calculating the volume of the composter:

$$
\begin{aligned}
\text { Reactor volume }= & \begin{array}{l}
\text { safety factor }(30 \%) \times \text { volume of compost material }+ \text { volume compost } \\
\text { material }
\end{array} \\
= & 31200 \mathrm{~cm}^{3}
\end{aligned}
$$

Thus, the reactor was a length, width and height of $30 \mathrm{~cm} \times 30 \mathrm{~cm} x 35 \mathrm{~cm}$, respectively.

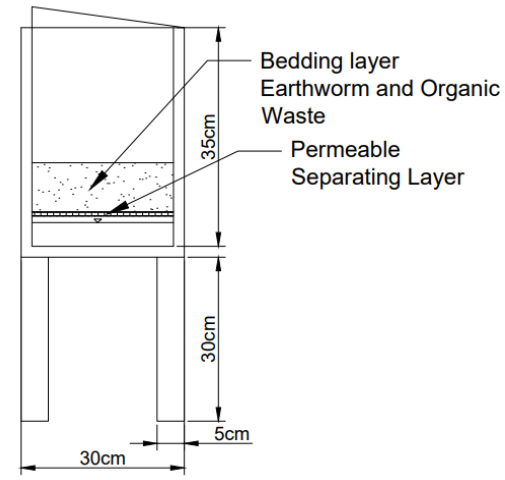

Fig. 1. Design of Composter

\subsection{Acclimatization by seeding sawdust for 48 hours in a composter}

This acclimatization served as an adjustment of the earthworm L. lumberus to the new environment. If the worms did not leave the reactor, the media in composting was suitable as a habitat for the earthworm L. lumberus [14].

\subsection{The vermicomposting process in this study is as follows:}

Vermicomposting process in this study beginning cut organic waste as compost material into 2-3 $\mathrm{mm}$ size. The smaller the size of the compost material would increase the surface area so that microbes can easily decompose organic compounds. In addition, the smaller size of the compost material could maintain air circulation in the composting process and the compost material then would be mixed homogeneously [4]. After that, the compost materials were mixed homogeneously so that the compost material decomposes evenly, and the compost material have indeed into the composter. Then, it mixed EM4 liquid (with doses $30 \mathrm{ml} / \mathrm{kg}$ of compost material). In this study the mass of compost material was 12.24 $\mathrm{kg}$ so that the total volume of EM4 solution required for each reactor was $367.2 \mathrm{ml}$. The last, earthworm L. lumberus were added to compost material was $100 \mathrm{gr}$ worme $/ \mathrm{kg}$ compost material (R2) and $250 \mathrm{gr}$ worms/kg compost material (R3). The mass of compost material 
in this study was $11.04 \mathrm{~kg}$ so that the total L. lumberus worms added in the reactor was 1.22 $\mathrm{kg}(\mathrm{R} 2)$ and the reactor was $2.76 \mathrm{~kg}(\mathrm{R} 3)$.

\subsection{Monitoring the composting process}

Physical parameters during the monitoring of composting process in this study consisted of moisture content, texture, temperature, color and particle size of manure. The method and frequency of measuring compost can be seen in Table 2 .

Table 2. Method of measuring moisture content, texture, temperature, and color during the composting process

\begin{tabular}{|l|l|l|l|}
\hline \multicolumn{1}{|c|}{ Parameters } & $\begin{array}{l}\text { Measurement } \\
\text { method }\end{array}$ & $\begin{array}{c}\text { Measurement } \\
\text { Equipment }\end{array}$ & \multicolumn{1}{|c|}{ Measurement Period } \\
\hline Temperature & In situ & Soil meter 3 in 1 & Everyday \\
\hline Moisture content & Gravimetri & Oven at $105^{0} \mathrm{C}$ & Every three days \\
\hline Texture and Color & In situ & Visual & Every three days \\
\hline Particle size & In situ & Sieve & End of composting process \\
\hline $\begin{array}{l}\text { Earthworm } \\
\text { L.lumberus weight }\end{array}$ & In situ & digital scales & $\begin{array}{l}\text { Strart and End of composting } \\
\text { process }\end{array}$ \\
\hline $\begin{array}{l}\text { Weight of } \\
\text { compost }\end{array}$ & In situ & digital scales & $\begin{array}{l}\text { Strart and End of composting } \\
\text { process }\end{array}$ \\
\hline
\end{tabular}

\subsection{Weight of earthworm L. lumberus and manure}

Measurement of the weight of earthworm L. lumberus and manure was carried out at the end of composting process ( 21 days). This was done to determine the increase or decrease in the weight of the earthworm L. lumberus and the percentage of mass shrinkage of the compost material.

\section{Result and Discussion}

\subsection{Temperature}

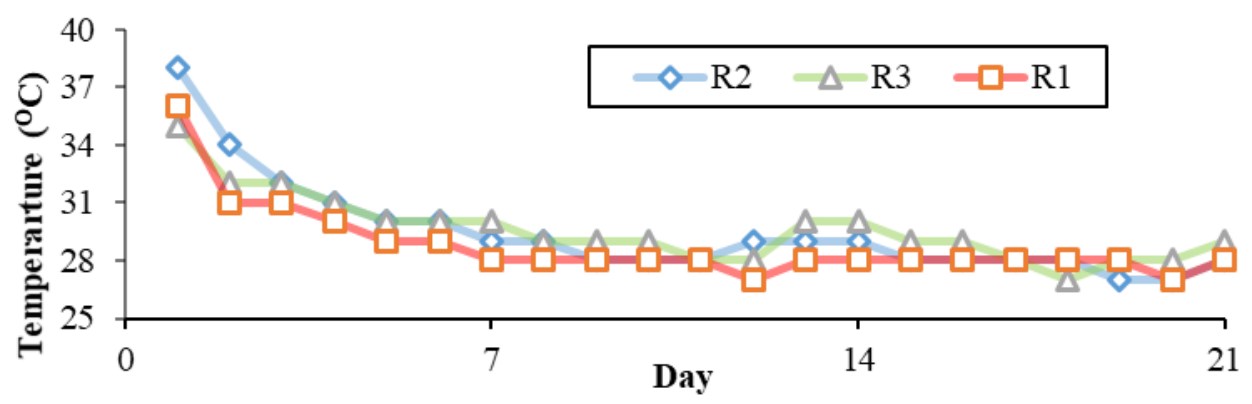

Fig. 2. Change temperature in to temperature during vermicomposting

Noted: R1 (no adding worms), R2 (adding 100gram worms $/ \mathrm{kg}$ organic waste), and R3 (adding 250 gram worms $/ \mathrm{kg}$ organic waste) 
According to $[11,20]$, the composting temperature has 3 phases consisting of mesophilic $\left(10-40.5^{\circ} \mathrm{C}\right)$, thermophilic $\left(>40.5^{\circ} \mathrm{C}\right)$, and psychophilic $\left(<10^{\circ} \mathrm{C}\right)$. The initial temperature of composting is generally characterized by a mesophilic or psychophilic phase. This depends on the ambient temperature and the temperature of the compost material. Figure 2. showed that the composting temperature in reactors 1,2 and 3 is the most extreme on day 1 to day 3 (above $30^{\circ} \mathrm{C}$ ). This indicates that the beginning of the composting process in this study entered the mesophilic phase. According to [10], this occurs because decomposition by microbes produces heat, causing high temperatures. At high temperatures $>160 \mathrm{~F}\left(71^{\circ} \mathrm{C}\right)$ can inhibit microbial activity. At a thermophilic temperature $\left(40.5^{\circ} \mathrm{C}-71^{\circ} \mathrm{C}\right)$ it is more effective and efficient in the composting process. In this study, maturation of compost material in R1, R2, and R3 began to occur after the 8th day $\left(<30^{\circ} \mathrm{C}\right)$. Temperatures below $30^{\circ} \mathrm{C}$ were ground water temperatures that identify mature compost [24]. The temperature fluctuation of compost in R1, R2, and R3 have not significant occurs in vermicomposting process

\subsection{Moisture Content}

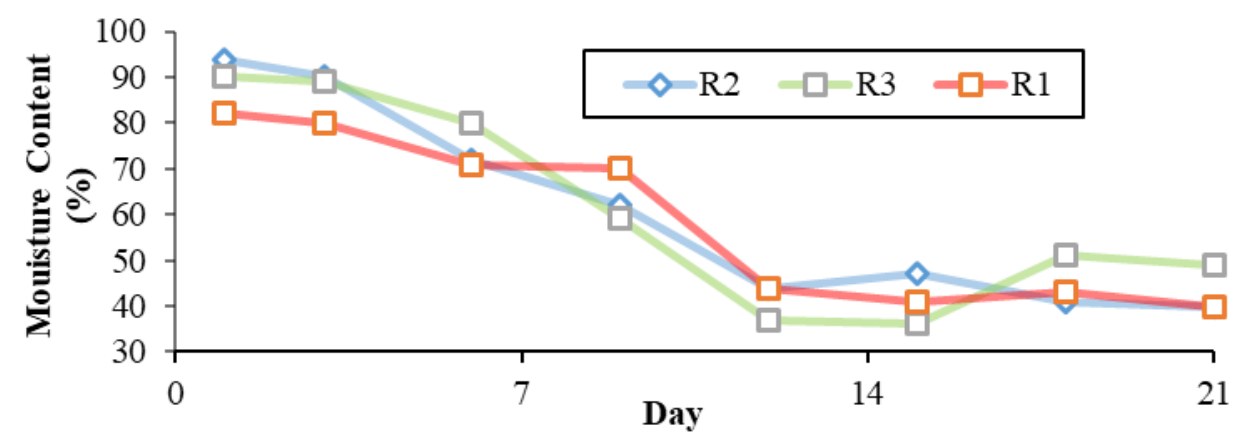

Fig. 3. Moisture content of manure during vermicomposting (dry basis)

Noted: R1 (no adding worms), R2 (adding 100gram worms / $\mathrm{kg}$ organic waste), and R3 (adding 250 gram worms $/ \mathrm{kg}$ organic waste)

According to [18] moisture content is one of the parameters of composting process that affects the microorganism activities such as distributing nutrients needed by microbial metabolic processes. Figure 3. showed that in reactors 1, 2 and 3, the moisture content of the composting waste decreased until the 12th day (below 50\%). According to [1], moisture content of composting process below $40 \%$ indicates microbial activity is decreasing because organic matter has decomposed. Day 1 to day 12 moisture content decreased due to microbial activity that produces heat (high temperature) [5]. The optimum moisture content in the vermicomposting process is between $65-85 \%[1,8,17]$. This indicates that the optimum of moisture content for earthworm L.lumberus as a decomposer occurs on day 1 to day 9. The moisture content fluctuation of compost in R1, R2, and R3 have no significant occurs in vermicomposting process.

According to [25], the quality of manure if the moisture content of the manure is $8-25 \%$ then the compost occurs mature. In this study, the moisture content in all reactors (R1, R2, and R3) at the end of composting process (day -21) was 30-40\%. The moisture content of manure in all reactors (R1, R2, and R3) was not yet mature compared to compost's 
moisture content [25]. However, vermicomposting was declared completed if the process had lasted for 6 to 12 weeks [16]. In this study, the vermicomposting process took only three weeks, but the texture and color were like manure. In order to make the moisture content meet the standards, vermicomposting process should be done with a longer time.

\subsection{Texture, color and particle size}

The vermicomposting process in this study lasted for 21 days. At the start of composting, compost raw materials still produce odors because there is no waste decomposition process by worms. Reactor 1, 2 and 3 produce no odor at day 12, 9 and 6, respectively. Due to the fact that the worms in reactor 3 can decompose the waste properly, the odor in reactor 3 disappeared faster than that of reactors 1 and 2.

On the first day of composting, the texture of the waste on R1, R2, and R3 was still in the form of vegetable pieces. On the third day, there was a change in the texture of the waste in the vermicomposting process. The grain size of manure on the third day at R1, R2, and R3 was $20 \%, 10 \%$ and $60 \%$, respectively. On day 21 , there was a significant increase in grain size in all reactors, in which the increased reached up to $90 \%$ at R1 and R2, and $95 \%$ at R3. Regarding solid organic fertilizers [25], the quality requirements for grain size $(2-4.75 \mathrm{~mm})$ in compost are at least $75 \%$. Therefore, results obtained from these three reactors have met the standards of compost based on the grain size [25]. On the first day of composting, the waste was still brightly colored in the three reactors. Color changes in the three reactors began to occur on the sixth day. At R1 and R2, the color of the compost changed to brown while at R3 the color of the manure changed to blackish brown. If the color of the compost is similar to the soil, it can be stated that the compost is completed and it can be used.

\subsection{Weight of earthworm L. lumberus}

Figure 4 described that weight of the worms analysis in this study was the weight of the worms in reactor 2 and reactor 3 . The weight of the initial worms used in reactor 2 was not the same asn the weight of the initial worms in reactor 3 . The weight of the initial worms used in reactor 2 was $1.22 \mathrm{~kg}$ while the initial worm weight used in reactor 2 was $2.76 \mathrm{~kg}$.

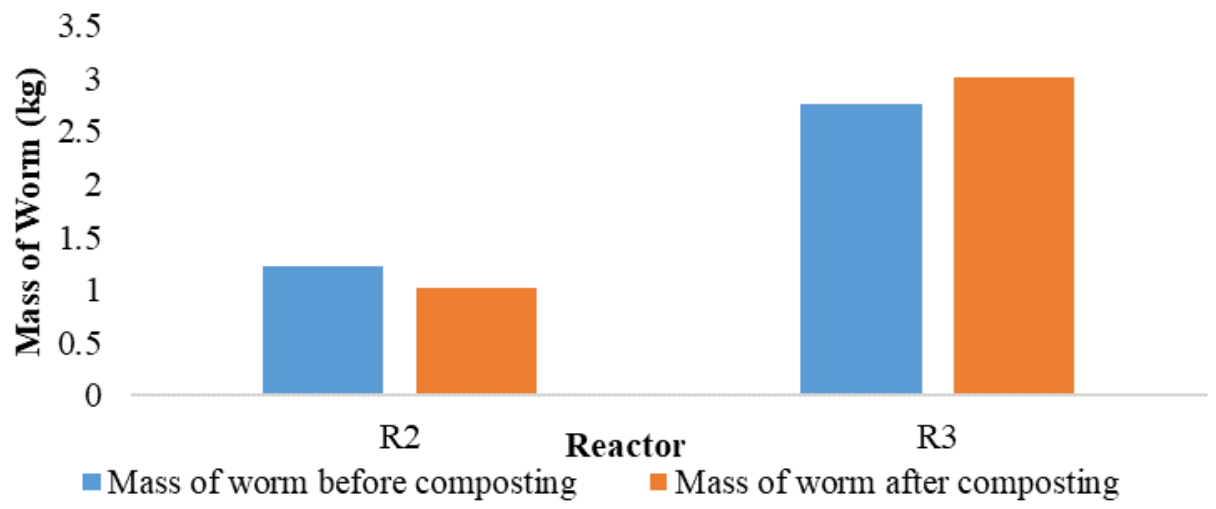

Fig. 4. Changes in mass of worm before and after vermicomposting process 
Noted: R2 (adding 100gram worms $/ \mathrm{kg}$ organic waste), and R3 (adding 250 gram worms $/ \mathrm{kg}$ organic waste)

After undergoing the vermicomposting process, there was a change in the weight of the worms in both reactor 2 and reactor 3 . In reactor 2, there was a decrease in the weight of the worms from $1.22 \mathrm{~kg}$ to $1.02 \mathrm{~kg}$ or $16.4 \%$ shrinkage. In contrast, the weight of the worms in Reactor 3 increased from $2.76 \mathrm{~kg}$ to $3.01 \mathrm{~kg}(8.3 \%)$. According to [3], the average weight of an adult worm is 2.3 grams, while that of a young worm is $0.8 \mathrm{~kg}$. According to research [16], worm biomass decreased from 6 to 12 weeks. In this study, vermicomposting lasted for 3 weeks, so that worm biomass decreased due to the formation of worm pupae. In reactor 3, worm biomass increased due to the presence of worms and the birth of new worms.

\subsection{Composting mass shrinkage}

Figure 5 presented that mass of manure before and after composting proocess for 21 days. Mass of manure decreased after 21 days composting because organic waste have degradated by microorganism.

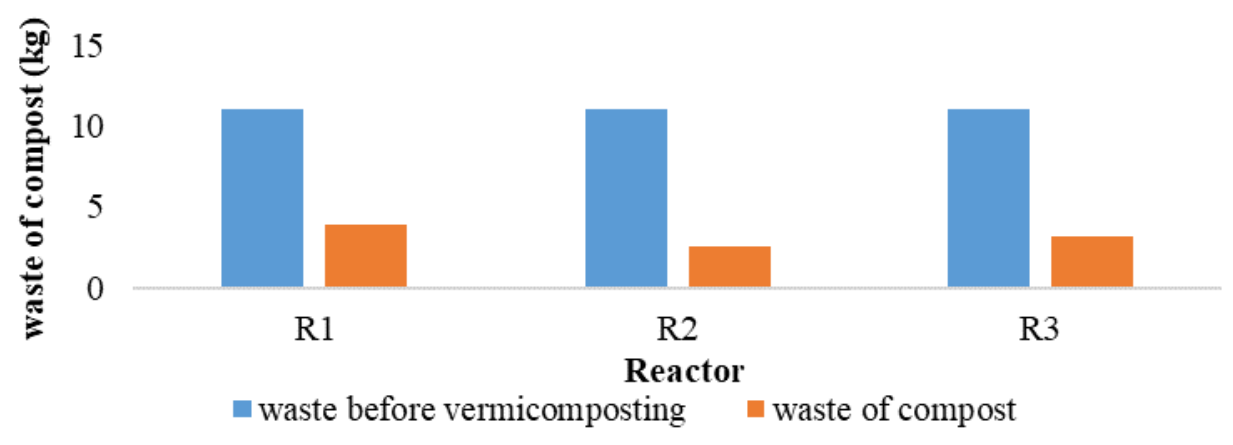

Fig. 5. Changes in mass of compost material before and after vermicomposting process Noted: R1 (no adding worms), R2 (adding 100gram worms $/ \mathrm{kg}$ organic waste), and R3 (adding 250 gram worms $/ \mathrm{kg}$ organic waste)

The initial weight of the waste used in reactors 1,2 , and 3 were $11.04 \mathrm{~kg}$. Reactor 1 did not use worms in composting, while reactors 2 and 3 use worms in composting. The results showed that the compost material shrinkage in reactors 2 and 3 was greater than in reactor 1 (Figure 5). The compost formed in reactors 1, 2, and 3 were $3.9 \mathrm{~kg}, 2.6 \mathrm{~kg}$; and $3.2 \mathrm{~kg}$, respectively. In addition, the percentage of compost material shrinkage in reactors 1,2 , and 3 were $64.67 \%, 76.45 \%$; and $71.01 \%$, respectively.

\section{Conclusion}

The characteristics of manure at R1 (no adding worms), R2 (adding 100gram worms $/ \mathrm{kg}$ organic waste), and R3 (adding 250 gram worms $/ \mathrm{kg}$ organic waste) were moisture contentof manure $\left(30-40 \%\right.$ ), and temperature (below $30^{\circ} \mathrm{C}$ ). In additon, at R1 and R2, the color of the compost changed to brown while at $\mathrm{R} 3$ the color of the manure changed to 
blackish brown. While, the shrinkage of worm weight that occurred in reactor 2 was $16.4 \%$. The weight gain of the worms in reactor 3 was $8.3 \%$. The particle size of the 21 st day compost $(2-4.75 \mathrm{~mm})$ at $\mathrm{R} 1, \mathrm{R} 2$, and $\mathrm{R} 3$ were $90 \%, 90 \%$, and $95 \%$ respectively The percentage of compost material shrinkage in reactors 1,2 , and 3 were $64.67 \%, 76.45 \%$; and $71.01 \%$, respectively

\section{References}

1. A.Khair, L.Herawati, Noraida, M.Raharja. Jurnal Kesehatan Masyarakat Nasional.10, 2, 62-66 (2015)

2. A. A. N. Katakulaa, B.Handuraa , W. Gawanab , F.Itanna, H. A. Mupambwaa. Scientific African 12, e00727 (2021)

3. C. H.Lalander, A. J. Komakech, B. Vinneras. Waste Management, 39, 96-103 (2015)

4. Damanhuri, E., Tripadmi, ITB, (2016)

5. D.A.P.Ratna, G.Samudro, S.Sumiyati. Jurnal Teknik Mesin (JTM), Vol. 06 edisi spesial (2017)

6. F. Alshehrei, F. Ameen. Saudi Journal of Biological Sciences. 28, 3284-3293 (2021)

7. F. Purba, Sutrisno, W. Endro, Irawan Wisnu. Jurnal Tek-Ling, 5, 4. (2016)

8. G.Munroe. Organic Agriculture Centre of Canada (2005)

9. K. Khwanchai, S. Kanokkorn. J. Environ. Sci. Technol, 11 , 23-27(2018)

10. L.Chen et al, M. De Haro Marti, A. Moore, C. Falen. The University of Idaho (2011)

11. M.S.Ayilara, O.S.Olanrewaju, O.O.Babalola and O.Odeyemi. Sustanaibility (2020)

12. M.Mago, A.Yadav,R.Gupta, V.K.Gargc. 2021. Bioresource Technology, 326, 124742 (2021)

13. M.Biruntha, N.Karmegam, J.Archana, B.K.Selvi, J.A.J. Paul, B.Balamuralikrishnan, S.W.Chang, B.Ravindran. Bioresource Technology, 297, 122398 (2020)

14. Rahmatullah, F., Sumarni, W., dan Susatyo, E.B. Indonesian Journal of Chemical Science, 2, 2,142-147 (2013)

15. R.Nsiah-Gyambibi. Gyambibi. H.M. K.Essandoh, N.Y. Asiedu, B.Fei-Baffoe. Heliyon, 7, e06422 (2021)

16. R.Nogales, C.Cifuentes, E.Ben'1tez. 40, 659-673 (2012)

17. S.Angima, M.Noack, S.Noack. Oktober, oregon state university, Archival copy. For current information, see the OSU Extension Catalog: https://catalog.extension.oregonstate.edu/em9034 (2011)

18. S. Gajalakshmi \& S. A. Abbasi. Critical Reviews in Environmental Science and Technology, 38, 5, 311-400 (2008)

19. S. Pattnaik, M. V. Reddy. Applied and Environ. Soil Science, $2010: 3$ (2010)

20. S. Vellaikkannu, R. Duraikannu, V. Mohan, S.V. Chathlingathe. Inter. Journal of biology Research, 3, 30-32 (2018)

21. United States Department of Agriculture (USDA). United States Department of Agriculture, Natural Resources Conservation Service and Potentials. Sustainability, 12, 4456; doi:10.3390/su12114456. MDPI journals sustanaibility (2020) 
22. Y.Cao, Y.Tian, Q.Wu, JiansheLi, H.Zhu. Bioresource Technology Volume 320, Part B, 124404 (2021)

23. Z. Nahrul Hayawin, H. P. S. Abdul Khalil, M. Jawaid., M. Hakimi Ibrahim, A.A Astimar. Environmentalist, 30, 273-278 (2010)

24. Badan standart Nasional. SNI 19-7030-2004 (2004)

25. Badan standart Nasional. SNI 7763:2018 (2018)

26. Badan standart Nasional. SNI 19-3964-1994 (1994)

27. A. Takhur, A. Kumar, C.V. Kumar, B.S. Kiran, S.Kumar, V. Athokpam. IK Press. Biology, 22, 156-164 (2021)

28. Asha Aalok, A.K. Tripathi and P. Soni. Journal of Human Ecology J. Hum. Ecol., 24,1, 59-64 (2008)

29. Tchobanoglous, G. dan Kreith, F.Mc Graw-Hill Companies, Inc. (2002)

30. The United States Departement of Agriculture (USDA). (2000) 